\title{
HUBUNGAN SPOUSELESS DENGAN SELF ESTEEM PADA LANSIA DI DESA RITEY KECAMATAN AMURANGTIMUR KABUPATEN MINAHASA SELATAN
}

\author{
Riska K Assa ${ }^{1}$, Minar Hutauruk ${ }^{2}$, Adriani Natalia ${ }^{3}$ \\ ${ }^{1}$ Mahasiswa Program Studi Ilmu Keperawatan Fakultas Kedokteran Universitas Sam \\ Ratulangi \\ ${ }^{2}$ Politeknik Kesehatan Kementerian Kesehatan Manado \\ ${ }^{2}$ Program Studi Ilmu Keperawatan Fakultas Kedokteran Universitas Sam Ratulangi \\ Email : Riskakristina19@gmail.com
}

\begin{abstract}
The elderly are a group of people aged 60 years and over. Advanced age is said to be the final stage of development in the human life cycle. Loss is a situation that can be experienced by individuals when there is a change in life or parting with something that previously existed. Spouseless is one of the biggest sources of stress in the elderly. Self-esteem is a person's evaluation of himself is positive or negative. The purpose of this study was to determine the spouseless with self esteem in the elderly in Ritey village of East Amurang district of South Minahasa regency. The research method that was used correlative study design with cross sectional study. The sample research used the purposive sampling of 36 respondents. The research instrument used the Rosenberg Self-Esteem scale. The analysis conducted was univariate analysis used frequency distribution and bivariate used Fisher's Exact Test with SPSS program version 25.0. Conclusion the results showed Spouseless with self esteem in the elderly in Ritey village of East Amurang district of South Minahasa regency with $p$ value = $0,019<\alpha=0,05$.
\end{abstract}

Keyword : Elderly, Spouseless, self esteem

\begin{abstract}
Abstrak : Lanjut usia adalah kelompok manusia yang berusia 60 tahun keatas. Usia lanjut dikatakan sebagai tahap akhir perkembangan pada daur kehidupan manusia. Kehilangan adalah suatu situasi yang dapat dialami individu ketika adanya perubahan dalam kehidupan atau berpisah dengan sesuatu yang sebelumnya ada. Kehilangan pasangan merupakan salah satu sumber stres terbesar pada lansia. Harga diri merupakan evaluasi seseorang terhadap dirinya sendiri bersifat positif atau negatif. Tujuan penelitian ini adalah untuk mengetahui hubungan kehilangan pasangan dengan harga diri pada lansia di Desa Ritey Kecamatan Amurang Timur Kabupaten Minahasa Selatan. Metode penelitian ini menggunakan desain penelitian correlative study dengan pendekatan cross sectional study. Sampel penelitian diambil dengan cara purposive sampling sebanyak 36 responden. Alat ukur penelitian ini menggunakan kuesioner Rosenberg Self-Esteem scale. Analisa yang dilakukan adalah analisa univariat menggunakan distribusi frekuensi dan bivariat menggunakan uji Fisher's Exact Test dengan program SPSS versi 25.0. Hasil penelitian menunjukan adanya hubungan antara kehilangan pasangan dengan harga diri pada lansia di Desa Ritey Kecamatan Amurang Timur Kabupaten Minahasa Selatan dengan nilai $p$ value $=0,019<\alpha=0,05$.
\end{abstract}

Kata kunci : Lanjut usia, kehilangan pasangan, harga diri 


\section{PENDAHULUAN}

Tahap akhir dalam rentang kehidupan manusia adalah lanjut usia (lansia), yang ditandai dengan berbagai perubahan fisik, psikis maupun sosial (Keliat, Helena, \& Farida, 2011). Data dari World Population Ageing (2019) menjelaskan populasi lansia merupakan fenomena global. Terdapat 703 juta orang berusia 65 tahun atau lebih di dunia pada tahun 2019 dan diperkirakan jumlah lansia akan bertambah dua kali lipat menjadi 1,5 miliar pada tahun 2050 (United Nations, 2019).

Hasil proyeksi penduduk 2010-2035, Indonesia akan memasuki periode lansia (ageing), dimana 10\% penduduk akan berusia 60 tahun ke atas, di tahun 2020 (Kemenkes RI, 2016). Pada tahun 2019, presentase lansia mencapai 9,60 persen atau sekitar 25,64 juta orang. Data menunjukan bahwa provinsi Sulawesi Utara merupakan provinsi kelima berdasarkan urutan presentase penduduk lansia terbanyak di Indonesia yaitu sekitar 11,15 persen (Badan Pusat Statisik, 2019).

Tugas perkembangan yang diemban lansia berupa penyesuaian diri terhadap penurunan-penurunan yang terjadi, penurunan tersebut baik berupa fisik maupun psikologis dimana lansia memiliki tugas untuk menyesuaikan diri dengan datangnya kematian (Dinakaramani 2018). Tidak seorang pun sanggup membayangkan akan ditinggal meninggal oleh orang yang terdekat (pasangan hidup) baik istri maupun suami. Terlebih lagi jika mereka telah hidup bersama sebagai pasangan suami istri selama belasan bahkan puluhan tahun (Desiningrum 2014).

Kehilangan pasangan adalah salah satu pemicu gangguan psikologis dalam bentuk kesedihan yang berulang (Tseng, Petrie, \& Gonzales 2017). Data menurut Badan Pusat Statistik (2019), presentasi penduduk lansia menurut status perkawinan dengan cerai mati $35,91 \%$, cerai hidup $2,31 \%$, dan belum kawin $1,05 \%$.

Kondisi kehilangan pasangan hidup merupakan salah satu tantangan emosional lansia terbesar yang mungkin dihadapi.
Lansia yang tidak siap menghadapi hari tua tanpa pasangan hidup tidak akan merasakan kepuasan dan kemaknaan hidup seperti yang diharapkan, bahkan banyak diantara mereka yang merasa tidak bahagia, depresi ataupun juga kesepian (Kartini 2017). Depresi merupakan akibat dari harga diri rendah pada lansia yang menjadikan seorang lansia itu menarik diri dari lingkungannya, putus asa, dan merasa tidak berdaya. Masalah-masalah harga diri meningkat pada lansia karena adanya tantangan baru yang salah satunya adalah kehilangan pasangan (Nauli 2014).

Harga diri adalah penilaian harga diri pribadi seseorang berdasarkan seberapa baik perilakunya cocok dengan ideal diri. (Stuart, 2016). Harga diri adalah penilaian terhadap dirinya sendiri secara rendah atau tinggi. Seorang lansia yang memiliki harga diri yang tinggi dapat menurunkan tingkat stress, Sebaliknya seorang lansia dengan harga diri rendah kurang memiliki keyakinan akan penerimaan dari orang lain (Rasadi 2014). Akibat dari harga diri rendah pada lansia yaitu lansia cederung tidak nyaman secara sosial misalnya bicara di depan umum dan berada di kerumunan orang (Azizah 2016).

Penelitian yang dilakukan setianingsih dkk (2019) menunjukan hasil bahwa sebagian besar lansia mengalami harga diri rendah. Penelitian juga yang dilakukan oleh Cicirelli (2018) menunjukan bahwa lansia dengan self-esteem yang tinggi tidak merasakan cemas terhadap kematian.

Hasil survey data awal yang ada di Desa Ritey Kecamatan Amurang Timur, Kabupaten Minahasa Selatan, bahwa terdapat 152 orang lanjut usia dengan jumlah laki-laki 74 orang dan perempuan 78 orang dimana jumlah lansia yang berstatus tidak memiliki pasangan hidup yang cerai mati, cerai hidup atau tidak pernah menikah yaitu 40 orang lanjut usia. Hasil wawancara awal peneliti dengan beberapa lansia diantaranya mengungkapkan bahwa dirinya merasa kesepian, sedih dengan keadaan sekarang. Perasaan tersebut semakin bertambah 
ketika fisik mereka menurun, karena lansia tersebut tidak bisa terlalu beraktifitas untuk mengurangi atau menghilangkan perasaan yang dialami.

Berdasarkan data di atas, menyatakan bahwa semakin meningkatnya Usia Harapan Hidup lanjut usia di dunia bahkan di Indonesia sendiri. Namun tidak dapat dipungkiri bahwa pada masa lanjut usia kita harus dihadapkan dengan kematian atau kehilangan pasangan hidup kita. Diketahui bahwa kehilangan pasangan dapat mengakibatkan kesepian pada lansia, dikarenakan tidak adanya dukungan dari pasangan hidup yang dimana sebagai sistem pendukung yang efektif.

Individu lansia yang kesepian cenderung menilai dirinya sendiri tidak berguna, tidak bernilai dan kurang berharga. Hal ini menurut peneliti akan menyebabkan harga diri lansia tersebut rendah. Jika harga diri rendah terjadi pada lansia maka akan menyebabkan depresi sehingga lansia menarik diri dari lingkungannya, menimbulkan pikiran negative, kurang percaya diri yang dimana akan mempengaruhi kualitas hidup lansia.

Berdasarkan hasil data diatas maka penulis ingin meneliti apakah ada hubungan spouseless dengan self esteem pada lansia di Desa Ritey Kecamatan Amurang Timur Kabupaten Minahasa Selatan.

\section{METODE PENELITIAN}

Penelitian yang dilakukan adalah penelitian kuantitatif menggunakan desain correlative study dengan pendekatan cross sectional study. Populasi dalam penelitian ini adalah seluruh lansia yang berstatus tidak memiliki pasangan hidup yang cerai mati maupun cerai hidup di Desa Ritey Kecamatan Amurang Timur, Kabupaten Minahasa Selatan dengan total populasi adalah 40 orang. Pengambilan sampel dengan menggunakan Purposive sampling dengan rumus slovin didapatkan sampel berjumlah 36 lansia. Alat ukur yang digunakan yaitu kuesioner Rosenberg's Self-esteem Scale (RSES) yang disusun oleh Rosenberg (1965) reliabilitas internal RSES yaitu sebesar 0,990 dengan menggunakan penilaian skala Likert. Data analisis melalui analisa univariat dan bivariat dengan menggunakan uji Fisher's Exact Test dengan tingkat kepercayaan $95 \%$ atau tingkat kemaknaan $\alpha=0,05$. Uji statistic menggunakan program statistic computer.

\section{HASIL PENELITIAN}

Karakteristik Responden

Tabel 1. Distribusi Frekuensi Responden Berdasarkan Umur Lansia

\begin{tabular}{ccc}
\hline Karakteristik Umur & $\mathbf{n}$ & $\mathbf{\%}$ \\
\hline 60-74 Tahun & 29 & 80,6 \\
\hline 75-90 Tahun & 7 & 19,4 \\
\hline$>$ 90 Tahun & 0 & 0 \\
\hline Total & $\mathbf{3 6}$ & $\mathbf{1 0 0}$ \\
\hline
\end{tabular}

Berdasarkan data pada tabel 1 tentang frekuensi responden berdasarkan umur lansia menunjukan dari 36 responden terbanyak berada pada kelompok usia 60-74 tahun yaitu sebanyak 29 responden $(80,6 \%)$.

Tabel 2. Distribusi Frekuensi Responden Berdasarkan Jenis Kelamin Lansia

\begin{tabular}{ccc}
$\begin{array}{c}\text { Karakteristik } \\
\text { Jenis Kelamin }\end{array}$ & n & \% \\
\hline Perempuan & 25 & 69,4 \\
\hline Laki-laki & 11 & 30,6 \\
\hline Total & $\mathbf{3 6}$ & $\mathbf{1 0 0}$ \\
\hline
\end{tabular}

Berdasarkan data pada table 2 mengenai frekuensi responden berdasarkan jenis kelamin didapati dari 36 responden menunjukan bahwa sebagian besar responden berjenis kelamin perempuan sebanyak 25 responden $(69,4 \%)$

Tabel 3. Distribusi Frekuensi Responden Berdasarkan Tingkat Pendidikan Lansia

\begin{tabular}{ccc}
\hline Tingkat Pendidikan & $\mathbf{n}$ & $\mathbf{\%}$ \\
\hline Tidak Sekolah & $\mathbf{6}$ & $\mathbf{1 6 , 7}$ \\
\hline SD & 16 & 44,4 \\
\hline SMP & 8 & 22,2 \\
\hline SMA & 5 & 13,9 \\
\hline Perguruan Tinggi & 1 & 2,8 \\
\hline Total & $\mathbf{3 6}$ & $\mathbf{1 0 0}$
\end{tabular}


Berdasarkan data pada table 3 tentang frekuensi responden berdasarkan tingkat pendidikan menjelaskan bahwa dari 36 reponden menunjukan sebagian besar sebanyak 16 responden $(44,4 \%)$ didapati tingkat pendidikan yaitu SD.

\section{Analisis Univariat}

Tabel 4 Distribusi Frekuensi Spouselss

\begin{tabular}{ccc}
\hline $\begin{array}{c}\text { Karakteristik } \\
\text { Kehilangan Pasangan }\end{array}$ & n & \% \\
\hline Cerai Mati & 27 & 75 \\
\hline Cerai Hidup & 9 & 25 \\
\hline Total & $\mathbf{3 6}$ & $\mathbf{1 0 0}$ \\
\hline
\end{tabular}

Berdasarkan data pada table 4 tentang distribusi frekuensi dari spouseless di atas menunjukan bahwa responden lansia didapati sebagian besar mengalami kehilangan pasangan dengan cerai mati sebanyak 27 responden $(75 \%)$.

Tabel 5. Distribusi Frekuensi Self Esteem

\begin{tabular}{|ccc|}
$\begin{array}{c}\text { Karakteristik } \\
\text { Harga diri }\end{array}$ & n & $\mathbf{\%}$ \\
\hline Harga Diri Tinggi & 15 & 41,7 \\
\hline Harga Diri Rendah & 21 & 58,3 \\
\hline Total & $\mathbf{3 6}$ & $\mathbf{1 0 0}$ \\
\hline
\end{tabular}

Berdasarkan data pada table 5.5 tentang distribusi frekuensi dari self esteem di atas menunjukan bahwa responden lansia mayoritas mengalami harga diri rendah sebanyak 21 responden $(58,3 \%)$.

\section{Analisis Bivariat}

Table 6. Hubungan Spouseless dengan Self Esteem Pada Lansia di Desa Ritey Kecamatan Amurang Timur Kabupaten Minahasa Selatan

\begin{tabular}{lcccccc}
\hline $\begin{array}{l}\text { Kehilangan } \\
\text { Pasangan } \\
\text { Spouseless) }\end{array}$ & $\begin{array}{c}\text { Harga Diri } \\
\text { Tinggi }\end{array}$ & \multicolumn{2}{c}{$\begin{array}{c}\text { Harga Diri } \\
\text { Rendah }\end{array}$} & Total \\
\cline { 2 - 7 } & $\mathrm{N}$ & $\%$ & $\mathrm{~N}$ & $\%$ & $\mathrm{~N}$ & $\%$ \\
\hline Cerai Mati & 8 & 29,6 & 19 & 70,4 & 27 & 100 \\
\hline Cerai Hidup & 7 & 77,8 & 2 & 22,2 & 9 & 100 \\
\hline Total & 15 & 41,7 & 21 & 58,3 & 36 & 100 \\
\hline$\alpha=0,05$ & P value $=0,019$ & & & &
\end{tabular}

Berdasarkan pada table 5.7 tentang Hubungan Spouseless dengan Self Esteem Pada Lansia di Desa Ritey Kecamatan
Amurang Timur Kabupaten Minahasa Selatan diatas menunjukan bahwa dari 27 responden lansia yang cerai mati didapati sebagian besar sebanyak 19 responden $(70,4 \%)$ mengalami harga diri rendah, sedangkan untuk 9 responden lansia yang cerai hidup didapati sebagian besar mengalami harga diri tinggi sebanyak 7 responden $(77,8 \%)$.

Berdasarkan analisa dengan menggunakan uji Fisher's Exact Test dengan program SPSS versi 25.0 didapatkan $\mathrm{p}$ value $=0,019$ $<\alpha=0,05$ artinya Ha diterima berarti ada hubungan spouseless dengan self esteem pada lansia di desa Ritey Kecamatan Amurang Timur, kabupaten Minahasa Selatan.

\section{PEMBAHASAN}

Karakteristik usia responden lanjut usia pada penelitian ini sebagian besar berusia diantara 60-74 tahun yang termasuk dalam kelompok usia elderly. Sesuai dengan definisi WHO (dalam Sunaryo, 2016) usia lanjut dibagi menjadi empat kriteria salah satunya elderly yaitu seseorang yang berusia 60-74 tahun. Hasil penelitian ini juga didukung dengan data Kemenkes RI (2016) bahwa Usia Harapan Hidup di Indonesia mengalami peningkatan 68,6 per tahun menjadi 70,8 per tahun dan bisa mencapai 72,2 per tahun, yang termasuk pada kelompok usia elderly.

Hasil penelitian menunjukan sebagian besar lansia berjenis kelamin perempuan dibandingkan dengan laki-laki. Data menurut Kemenkes RI (2016) menyatakan bahwa penduduk lansia yang paling banyak adalah perempuan, sehingga menunjukan bahwa harapan hidup yang paling tinggi adalah perempuan. Menurut Nauli (2014) penyesuaian terhadap kematian pasangan atau perceraian sangat sulit bagi pria maupun wanita pada usia lanjut, karena pada masa ini semua penyesuaian baik perubahan secara fisik, psikis dan sosial sulit dilakukan.

Berdasarkan tingkat pendidikan diketahui sebagian besar responden memiliki latar belakang pendidikan sekolah dasar. Sejalan 
dengan data dari Badan Pusat Statistik Lanjut Usia (2019) bahwa pendidikan penduduk lansia yang relatif masih rendah yaitu sebagian besar lansia berpendidikan rendah (SD/sederajat ke bawah). Rata-rata lama sekolah lansia sebesar 4,9 tahun atau setara dengan kelas $4 \mathrm{SD} /$ sederajat, dengan tingkat pendidikan rendah didapati lebih banyak berada didaerah pedesaan, sehingga sejalan dengan tempat penelitian yang dilakukan oleh peneliti yang dimana berada didaerah pedesaan. Menurut Yuni (2014) dimana tingkat pendidikan mempengaruhi individu dalam hal menghadapi masalah untuk menghindari stress, semakin tinggi tingkat pendidikan maka toleransi dan kontrol terhadap stressor akan menjadi lebih baik.

Hasil uji menggunakan Fisher's Exact Test dengan program SPSS versi 25.0 menunjukan bahwa $\mathrm{p}$ value $=0,019<\alpha$ $=0,05$ artinya $\mathrm{Ha}$ diterima berarti ada hubungan spouseless dengan self esteem pada lansia di desa Ritey Kecamatan Amurang Timur, Kabupaten Minahasa Selatan. Sedangkan dari koefisien korelasi didapatkan nilai $r=-0,423$, hal ini berarti keeratan hubungan antara spouseless dengan self esteem pada lansia adalah sedang, dan berarah negatif. Didapatkan hasil odd ratio $(\mathrm{OR})=0,120$ dan $\mathrm{CI}=$ $(0,020-0,710)$ hal ini berarti lansia yang cerai mati mempunyai resiko 0,120 lebih tinggi untuk mengalami harga diri rendah dibandingkan lansia yang cerai hidup.

Hasil penelitian ini didapatkan hasil yang terbagi menjadi dua yaitu lansia yang dengan cerai mati mengalami harga diri rendah, sedangkan yang cerai hidup mengalami harga diri tinggi. Tingkat harga diri seseorang mempunyai konsekuensi penting terhadap pembentukan tingkah laku individu. Bagaimana seseorang berhubungan dengan dirinya berpengaruh dengan bagaimana ia berhubungan pada orang lain (Maliana, 2016).

Kondisi cerai mati pada lansia tidak dapat dihindari, karena suatu saat salah satu pasangan kita akan meninggal. Lansia yang ditinggal mati pasangan dan memiliki karakteristik harga diri yang rendah mereka memiliki skor tertinggi pada item pernyataan harga diri yaitu "Saya berharap saya dapat lebih dihargai" dan pada item "Saya merasa bahwa kadang - kadang diri saya tidak baik sama sekali”. Hal ini merupakan salah satu faktor yang mempengaruhi bahwa lansia yang ditinggal mati pasangannya memiliki harga diri rendah.

Pernyataan jawaban responden tidak setuju terbanyak pada item harga diri yaitu "Saya merasa bahwa saya memiliki sejumlah kualitas yang baik dari diri saya", hal ini menunjukan bahwa lansia merasa tidak memiliki potensi dalam dirinya, tidak mampu menghadapi masalah dilihat dari proses penuaan yang terjadi dengan merasa tidak berdaya dan kehilangan salah satu sumber pendukung utamanya akibat kematian.

Sejalan dengan penelitian Narullita (2017) menunjukan bahwa harga diri rendah dapat dialami lansia, dimana lansia menghadapi berbagai perubahan baik fisik dan psikososial yang ditandai dengan adanya pikiran-pikiran negatif terhadap dirinya, seperti merasa tidak puas dengan dirinya sendiri, merasa dirinya tidak baik, merasa tidak mempunyai kemampuan yang baik, merasa tidak mampu melakukan segala sesuatu dengan baik sebagaimana orang lain.

Lansia yang cerai hidup pada penelitian ini ternyata memiliki harga diri yang tinggi dikarenakan hasil jawaban responden dari item pernyataan harga diri menunjukan bahwa lansia yang cerai hidup terbanyak memilih sangat setuju pada pernyataan harga diri yaitu "Saya menerima keadaan diri saya seperti apa adanya", dihubungkan dengan responden memilih sangat tidak setuju pada pernyataan harga diri yaitu "Saya merasa tidak banyak yang dapat saya banggakan pada diri saya".

Ternyata kondisi cerai hidup pada lansia terjadi disaat lansia belum memasuki usia tua, sehingga lansia diwaktu mengalami cerai hidup masih memiliki mekanisme koping yang baik, dan telah menerima 
perubahan kondisi sampai memasuki usia tua tanpa adanya pasangan hidup, ditambah dengan lansia yang cerai hidup rata-rata dari mereka telah ditinggalkan selama 12 sampai 20 tahun. Sesuai dengan teori Rathus \& Nevid (dalam Widyowati, 2013) menjelaskan bahwa individu baru dapat menerima kehilangan seseorang terutama orang terdekat setelah 2 sampai 3 tahun.

Penelitian tentang pasangan hidup dan harga diri pernah diteliti oleh Setiyawati (2017) menunjukan bahwa lansia yang ditinggal mati pasangannya termasuk dalam kategori harga diri rendah dimana lansia kurang aktif mengikuti kegiatan-kegiatan sebayanya sehingga lansia akan merasa kesepian karena kurang berinteraksi sosial dengan orang lain dan dukungan sosial yang kurang, dan lansia yang bercerai memiliki harga diri yang tinggi dikarenakan lansia memiliki penyesuain diri yang baik terhadap kehilangan pasangan sehingga tidak terlalu merasa kesepian ketika ditinggal oleh pasangan hidupnya.

Dengan demikian ketika semua lansia yang masih hidup dengan status kehilangan pasangan dan mengalami harga diri yang rendah, maka akan membuat lansia merasa tidak berguna, putus asa, dan memiliki penilaian terhadap diri rendah. Untuk mengantisipasi terjadinya harga diri rendah pada lansia yang cerai mati, maka diperlukan dukungan dari berbagai pihak, misalnya dari tenaga Kesehatan di pelayanan lanjut usia, puskesmas atau tempat pelayanan lainnya untuk mengantisipasi pada saat lansia tersebut mengalami penurunan harga diri

Diharapkan lansia tersebut dapat memiliki kebahagiaan serta kesuksesan di masa tua. Kebahagiaan dan kesuksesan lansia dapat tercapai dengan terpenuhinya kebutuhan akan kesejahteraan psikologis. Sesuai dengan penelitian Desiningrum (2014) menyatakan bahwa seseorang yang memiliki kesejahraan psikologis yang tinggi, mampu bertahan dari tekanan sosial, serta mampu menunjukkan sikap positif terhadap dirinya,

\section{Keterbatasan Penelitian}

Kuesioner Rosenberg Self-esteem Scale yang telah digunakan tidak dilakukan pengujian kembali yaitu untuk menguji validitas dan reabilitasnya. Sampel yang digunakan hanya 36 responden. Dalam kondisi sekarang ditengah pandemik Covid 19 peneliti mengalami kendala dengan tidak memungkinkan untuk melakukan aktifitas yang lebih leluasa dengan responden. Peneliti tidak memperhatikan dukungan keluarga, status ekonomi dan pekerjaan atapun variable lainnya yang mungkin dapat mempengaruhi tingkat harga diri lansia yang mengalami cerai hidup atau cerai mati.

\section{SIMPULAN}

Sebagian besar responden berusia diantara 60-74 tahun, berjenis kelamin perempuan, dan memiliki latar belakang pendidikan sekolah dasar. Lansia yang kehilangan pasangan mayoritas mengalami cerai mati dibandingkan dengan cerai hidup, dan mayoritas lansia mengalami harga diri rendah dari pada harga diri tinggi.

Hubungan Spouseless dengan Self esteem Pada Lansia di Desa Ritey Kecamatan Amurang Timur Kabupaten Minahasa Selatan, menggunakan uji statistic Fisher's Exact Test diperoleh hasil ada hubungan yang bermakna antara Spouseless dengan Self esteem pada lansia.

\section{DAFTAR PUSTAKA}

Badan Pusat Statistik (2019). Statistic Penduduk Lanjut Usia. https://www.bps.go.id/publication/ 2019/112/20/ab17e75dbe630e0511 ae 53b/statistik-penduduk-lanjutusia-2019.html diakses pada tanggal 10 Maret 2020

Desiningrum, D. R. (2014). Kesejahtraan psikologis lansia janda/duda ditinjau dari persepsi terhadap dukungan social dan gender. Jurnal psikologi undip vol 13 102-106. Diakses tanggal 21 Februari 2020. http://ejournal.undip.ac.id/index.ph 
p/psikologi/article/viewFile/8081/6 $\underline{628}$

Dinakaramani, S \& Indati, A. (2018). Peran Kearifan (Wisdom) terhadap kecemasan menghadapi kematian pada lansia. Jurnal Psikologi volume 45 no 2 181-188. Diakses tanggal 20 februari 2020.

Kartini, A., \& Wahyudi, C. T. (2017). Hubungan mekanisme koping dengan harga diri pada lansia yang ditinggalkan pasangan hidupnya diwilayah kelurahan Limo Depok. Diakses tanggal 22 februari 2020.

Kementerian kesehatan RI. (2016). Situasi lanjut usia (lansia) di Indonesia 2016.

http://pusdatin.kemkes.go.id/article /viev/16092300002/infodatinsituasi-lanjut-usia-lansia-diindonesia.html diakses tanggal 20 Februari 2020.

Narullita Dewi (2017). Faktor-Faktor Yang Mempengaruhi Harga Diri Rendah Lansia di Kabupaten Bungo. Jurnal Endurance 2(3). Diakses tanggal 6 Mei 2020.

Nauli, F. A., Ismalinda, W., \& Dewi, A. P. (2014). Hubungan keberadaan pasangan hidup dengan harga diri pada lansia. Jurnal Kepearawan Jiwa, 2(1), 24-30. Nursalam. (2013). Metodologi penelitian ilmu keperawatan: pendekatan praktis edisi 3. Jakarta: Salemba Medika

Notoadmodjo, S. (2012). Metodologi penelitian kesehatan. Jakarta: Rineka Cipta

Nurdin, Adnil Edwin. (2012). Tumbuh Kembang Manusia. Jakarta : EGC

Padila. (2013). Buku Ajar Keperawatan Gerontik. Yogyakarta. Nuha Medika

Rasadi, R. K. P. (2014). Skripsi Hubungan antara harga diri dengan kesepian pada mahasiswa baru Angkatan 2013/2014 Universitas Sanata Dharma. Diakses 22 Februari 2020.

Robins, W. R (2010). Self-esteem Development from Young Adulthood to old age : a cohortsequential longitudinal study.

Rosenberg (1965). Rosenberg self esteem scale. Diperoleh tanggal 22 Februari 2020.

http://www.google.com/url?sa=t\&s ource $=$ Web\&rct $=\mathrm{j} \&$ url

Setiadi. (2013). Konsep dan Praktik Penulisan Riset Keperawatan. Edisi 2. Surabaya. Graha Ilmu.

Setianingsih., Kasatun, Y., Anggraeni, Y. (2019). Gambaran Harga Diri Lansia. Jurnal Keperawatan Volume 11.

Siregar. (2013). Metode Penelitian Kuantitatif dilengkapi dengan Perbandingan Perhitungan Manual dan SPSS. Jakarta: Kencana Prenada Media Group.

Widyowati Wiwit (2013). Resiliensi pada lansia yang ditinggal mati pasangan hidupnya. Diakses tanggal 20 februari 2020.

Stuart, G. W. (2016). Prinsip dan Praktik keperawatan kesehatan jiwa. In International Journal of Social Psychiatry. https://doi.org/10.1177/002076401 $\underline{66758}$

Sunaryo, dkk. (2016). Asuhan Keperawatan Gerontik. Yogyakarta, Penerbit Andi 